\title{
The Quiapo Leap: A Kierkegaardian Reading of the Religious Experience of the Black Nazarene Popular Devotion ${ }^{1}$
}

Rhochie Avelino E. Matienzo

\begin{abstract}
In 1521, the Spanish conquistadores brought Christian faith to the Philippine islands. Through centuries, this faith is infused with the indigenous culture of the people paving a way to what is known today as "Filipino popular devotion." One of the most famous among its rituals is the annual Traslación devotion in honor of the Black Nazarene in Quiapo, Manila. In recent decades, there has been a vast measure of literature on this religious phenomenon. However, most of them are either written by social scientists or religious experts and very seldom has it been explored in a philosophical manner. This paper aims to reflect on the religious experience of the Black Nazarene popular devotion in order to provide a philosophical appreciation of this unique Filipino faith, in particular, and to provide an avenue towards a deeper understanding indigenous culture and Christian faith, in general. In meeting this aim, the study invokes Søren Kierkegaard's existentialism and its discussion on "faith" illustrated in two of his renowned works Fear and Trembling and Concluding Unscientific Postscript.
\end{abstract}

Keywords: Black Nazarene, Traslación, leap of faith, double movement of faith

${ }^{1}$ The essay was originally presented at the International Conference for Inter-Religious and Inter-Cultural Dialogue in a Pluralistic World: Philosophical and Theological Perspectives, in Constanta, Romania, held on 1-2 June, 2016. The seminal theories of this work were formulated in "Kierkegaard goes to Quiapo," in Scientia (June 2014), 43-71.

(C) 2016 Rhochie Avelino E. Matienzo

http://www.kritike.org/journal/issue_19/matienzo_december2016.pdf

ISSN 1908-7330

(cc) BY-NC-ND 


\section{THE QUIAPO LEAP}

\section{Introduction}

$\mathrm{E}$ very $9^{\text {th }}$ of January, millions of barefooted men parade the streets of Quiapo, Manila, in the ardent hope of getting close to the $16^{\text {th }}$-century wooden figure of a suffering Christ. Since its first Traslación (Spanish for "passage") in 1787, numerous claims of miracles have been attached to the wooden figure. Based on the numbers recorded from 2004 to 2014, a significant increase of 4,000\% $(300,000-12,000,000)$ participated in the annual feast. ${ }^{2}$ However, because of the odd cultic character of the devotion, it is yet to be officially recognized by the Catholic Church. Considered as an "unofficial cult," ${ }^{3}$ the increasing cases of injuries, death, and damage to property ${ }^{4}$ each year has led both foreign and local observers to describe the

\footnotetext{
2 Agatha Guidaben, "March of the multitudes: Nazarene procession grows every year," in GMA News Online (9 January 2014), $<$ http://www.gmanetwork.com/news/story/343106/news/nation/march-of-the-multitudesnazarene-procession-grows-every-year>, 15 January 2014.

3 Bernhard Raas, Popular Devotions: Making Popular Religious Practices More Potent Vehicles of Spiritual Growth (Manila: Divine World Publications, 1992), 14-22. Peter Chan describes it "as unsophisticated, superstitious, emotional, individualistic, reactionary, and even antiliturgical" since devotees transform the mute image of Christ into a powerful relic. See Peter C. Chan, "Popular Religion, the Liturgy, and the Cult of the Dead," in East Asian Pastoral Review, 42:1-2 (2005), in East Asian Pastoral Institute (2005), <http://www.eapi.org.ph/resources/eapr/eastasian-pastoral-review-2005/volume-42-2005-number-1-2/popular-religion-the-liturgy-and-thecult-of-the-dead/>, 18 July 2013.

See also Paul VI, "Sacrosanctum Concilium," in The Holy See (4 December 1963), $<$ http://www.vatican.va/archive/hist_councils/ii_vatican_council/documents/vatii const 19631204 sacrosanctum-concilium en.html $>$, §13.

${ }^{4}$ From 2004 to 2016, reports indicate that there were of 8,484 people hurt and 11 lives lost during the annual "pamamanata." See the following: Charmie Joy Pagulong, "Timeline: Deaths, injuries, during Quiapo procession," in The Philippine Star Global (8 January 2012), $<$ http://www.philstar.com/headlines/765471/timeline-deaths-injuries-during-quiapoprocession>, 18 January 2014; Philippine News Agency, “2014 'Traslacion' of the Black Nazarene takes almost 19 hours," in Interaksyon (10 January 2014), $<$ http://interaksyon.com/article/78428/2014-traslacion-of-the-black-nazarene-takes-almost-19hours $>, 11$ January 2014; Aries Joseph Hegina and Bong Lozada, “2 dead, 2 hurt by electric shock in 19-hour Black Nazarene 'traslacion,'” in Inquirer.net (10 January 2015), $<$ http://newsinfo.inquirer.net/663671/1-dead-2-electrocuted-in-19-hour-black-nazarenetraslacion>, 10 January 2015.
}

(C) 2016 Rhochie Avelino E. Matienzo

http://www.kritike.org/journal/issue 19/matienzo december2016.pdf

ISSN 1908-7330

(c) $)$ BY-NC-ND 
phenomenon as "religious frenzy," 5 "idolatry,"6 "irrationality,"7 "fanaticism," 8 and "superstition." ${ }^{9}$ Despite calls for Catechism, government warnings of bomb threats, ${ }^{10}$ and death toll, there is no indication that the Quiapo phenomenon will be stopping anytime soon.

Hence, the following questions: Despite all the risks and criticisms, why do devotees increase each year? What are their intentions? What is the meaning enclosed in the religious experience of a devotee? What are the elements of such belief?

At present, while there exist a number of studies in anthropology, sociology, religion, and theology that investigate the Quiapo phenomenon, there are virtually no philosophical studies on it. ${ }^{11}$ The aim of this paper, therefore, is to philosophically understand the religious experience of the Black Nazarene popular devotion. In order to achieve this aim, I will adopt the 19th-century Danish existentialist Søren Kierkegaard's notion of "faith" as a methodology in coming up with a fresh understanding of the religious phenomenon. The choice of framework is based on the extensive study of "faith" illustrated in two of his major works: Fear and Trembling (1843) and Concluding Unscientific Postscript (1846). Both texts suggest that the highest meaning of life is achieved through one's experience of faith. This is

\footnotetext{
5 Sarah Brown and Firefly360, "The Annual Feast of the Black Nazarene," CNN iReport (9 January 2013), <http://ireport.cnn.com/docs/DOC-907647>, 15 May 2013.

${ }^{6} \mathrm{Ma}$. Carmen R. Gaerlan. "Hidden from the Clever: An Initial Study on Selected Religious Beliefs and Practicse of Filipino Popular Catholicism" in And God Said: 'Hala!' Studies in Popular Religiosity in the Philippines, ed. by Jaime A. Belita (Manila: De La Salle University Press, 1991), 137-148; Philip Tubeza, "Quiapo Priest: Filipino Devotion to Black Nazarene Not Idolatry," in Inquirer.net (9 January 2013), <http://newsinfo.inquirer.net/337495/quiapo-priest-filipinodevotion-to-black-nazarene-not-idolatry>, 9 January 2013; Raas, Popular Devotions, 22.

7 Jocelyn R. Uy, “Black Nazarene Devotees Displayed ‘Excess Fanaticism,' Says Quiapo Priest," in Inquirer.net (11 January 2012), <http://newsinfo.inquirer.net/125993/black-nazarenedevotees-displayed-\%E2\%80\%98excess-fanaticism\%E2\%80\%99-says-quiapo-priest $>, \quad 15$ May 2013.

8 Ibid.

${ }^{9}$ Eduardo Domingo, "Opium or Catalyst?: The Ambivalence of Religious Symbols in Social Change," in And God Said: 'Hala!' Studies in Popular Religiosity in the Philippines, ed. by Jaime A. Belita (Manila: De La Salle University Press, 1991), 56.

10 Windsor Genova, “Thousands of 'Black Jesus' Devotees Join Manila Procession Amid Bomb Threat" International Business Times (9 January 2012),

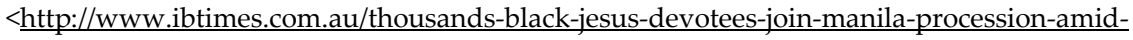
bomb-threat-1292219>, 14 January 2014.

${ }^{11}$ One of the pioneers in the study of popular religiosity, Jesuit Catalino Arevalo, urges researchers to investigate the spirituality of the Black Nazarene devotions for two reasons: first, it is an opportune occasion where people connect to their faith with God and second, there exists an insufficient number of studies conducted despite its prominence and immensity of followers. Cf. Jose Clemente F. Ignacio "Understanding the Devotion to the Black Nazarene," paper presented at the National Liturgical Congress, Loyola School of Theology, Quezon City, 19 January 2011.
} 


\section{THE QUIAPO LEAP}

illustrated in Kierkegaard's discussion of the "movements of faith"12 or, as widely known in the English speaking world, the "leap of faith." I also borrow the anthropological approach of "participative-observation" in order to describe the religious experience of the informant-devotees during the Traslación of 2014, 2015, and 2016 in Quiapo. Hence, the method is phenomenological but in the context of a "metasociological descriptive analyses" of the self-situation and social constitution experienced as features of the world..$^{13}$ Specifically, the study uses the "Lakaran" method ("journey on foot") which was initially performed by spirituality and culture scholars Teresita Obusan and Leonardo Mercado to cull out meanings beyond what is physically observed in the modern day Quiapo district. ${ }^{14}$ The methodology is informed by Apolinario "Hermano Pule" de la Cruz's (1815-1841) concept of a journey with fellow countrymen in order to empower themselves during the Spanish period. By literal walking on foot with the Quiapo devotees, the "hiyang" method is understood as "pakikipagkapwa" or "intersubjectivity."15 Through this, informant-devotees share own personal journeys with minimal hesitation and intimidation during the interviews.

\footnotetext{
12 Søren Kierkegaard, Fear and Trembling/Repetition, ed. and trans. by Howard Hong and Edna Hong (New Jersey: Princeton University Press, 1983) 18, 36-37, 58-59, 115, 119.

${ }^{13}$ Myron Orleans, "Phenomenology," in Encyclopedia of Sociology, $2^{\text {nd }}$ ed., vol. 3, ed. Edgar F. Borgatta and Rhonda J.V. Montgomery (New York: Macmillan Reference USA, 2000), 2099-2107. Cf. Brian Bantungan, "Recognizing Frames and Constructing Realities: The Implications of the Integration of Actual, Virtual and Augmenting Realities of the Optical Mediascape of Quiapo," paper presented at Media in Transition 6: Stone and Papyrus, Storage and Transmission, Massachusetts Institute of Technology, 24-26 April 2009.

${ }_{14}$ Teresita B. Obusan, Mystic or Mistake: Exploring Filipino Mysticism (Quezon City: Institute of Spirituality in Asia, 2008), 39-48. Mercado likewise used "lakaran" method associated with phenomenology in his study of the Black Nazarene in Quiapo and the Sto. Niño in Cebu City popular religiosity. He explains that the word "lakad" or "to walk" implies, "mayroon lakad" connotes "a task to perform," a "pilgrimage," a "mission." Lakaran becomes more than a sightseeing but a journey with a purpose. He adds, that as an evangelization tool, the method is effective since it is based on powerful symbolisms that attract deep faith among Filipinos (suffering Christ, child Jesus, iconography, etc.). Leonardo N. Mercado, "Lakaran: A Filipino Way of Proclaiming Christ," in Studia Missionalia, 51 (2002), 301-332.

${ }^{15}$ With this subjective approach, the meanings of the informants' experiences are objectively gathered. Talisayon has it, "intersubjectivity is more fundamental than, and is, the basis for establishing, objectivity." Serafin Talisayon, "Patotoo, An Indigenous Concept of Validity and Some Implications," in Hiyang: Papers of the Colloquium on Research Methodologies in the Study of Spirituality in the Philippines (June 28-30, 2004) (Quezon City: Carmelite Center for Spirituality, 2005), 56.

Despite informal interactions with the devotees in the conduct of this study, the interviews are guided by the following questions: a. Bakit ka nandito sa Quiapo? (motive of devotion); b. Paano ka namamanata? (mode of expressing faith); c. Ano ang 'di mo malilimutang karanasan sa pamamanata mo sa Señor? (religious experience, if any); d. Hanggang kailan mo ito gagawin? (passion/personal drive); and e. Sino si Señor para sa iyo, personally? (subjective and inward relation)
}

(C) 2016 Rhochie Avelino E. Matienzo

http://www.kritike.org/journal/issue 19/matienzo december2016.pdf

ISSN 1908-7330

(cc) BY-NC-ND 


\section{The Religious Experience of the Black Nazarene Devotees}

In this article, I will present three cases. First is "Glaiza" (refused to give her surname), a first-time devotee and a 28-year-old housewife from San Pedro, Laguna. She collapsed during her first "salang" (the gesture of touching the wooden figure and its garments) and who regained consciousness at the Mother and Child Hospital in Binondo, Manila. Upon waking up, she was advised by the physician to go home in order to recover. Instead, she went back to the frantic procession and touched the carroza for the second time. Her request is to have a child with the common law partner for three years. ${ }^{16}$ Based on her experience, one acts based on a certain trust that proceeds from within where one does not understand but can only experience. She said:

Mahirap ipaliwanag ang sarap na nararamdaman, iba ang emotion ... kahet pa nga hinimatay ako kanina sa dami ng tao at 'di na ko nakahinga ... Sa loob ko, meron nagtutulak sa akin kahet 'yung katawan ko pagod na pagod na, sa loob ko me nagsasabi na dapat ko gawin to.

(It's hard to explain that delightful feeling, a different emotion ... even if I collapsed earlier due to the excessive number of people when I wasn't able to breathe ... Within me, there is something that pushes me despite exhaustion, there is something inside me that tells me that I ought to do this). ${ }^{17}$

The second case is Apolinario "Tatay Boy" Maranan, a 74-year-old and 54 year-devotee. At his age, he attributes all the material and spiritual blessings he has received to the Black Nazarene and promises to keep the "panata" (sacred vow) in his remaining years. Tatay Boy is a native of Alitagtag, Batangas, and the current president of the Hijos-Nuestro Padre Jesus Nazareno (H.N.P.J.N.). During his grade school years, his family moved to Manila when his father became encargado (manager) of an ice cream factory in Sampaloc, Manila. One afternoon at the Quiapo church, he and his friend were playing around the Basilica when he saw the agonizing face of the image transformed into a smiling bright face. He rejected all media invitations for an exclusive interview to keep this secret (and asked me to do likewise). In

\footnotetext{
16 On 26 January 2015, the researcher was informed that she (Glaiza) gave birth to healthy girl named "Aryhan."

${ }^{17}$ An interview with "Glaiza" at Park and Ride, Lawton, Manila (9 January 2014, 6:32 PM).
} 


\section{THE QUIAPO LEAP}

his testimonies, subjectivity serves as a defining trait of his faith, particularly when asked whether to consider what happened in his early days, a form of miracle. He replies:

Para sa'kin, walang himala pero ang mga imposibleng mangyare, possibleng mangyare sa kalooban mo... walang katiyakan... sa lahat ng pangyayare sa buhay ... sa paniniwala mo at sa paniniwala ng ibang tao, maaaring magkakaiba, pero isa lang ang pupuntahan, pananampalataya.

(For me, there is no miracle yet those impossible to happen, are possible to happen inside you... no certainty, whatever happens in life ... in your belief at other people's belief, possibly different, but they all lead to one, faith). ${ }^{18}$

The third case is Raymond "Imon" Gappi. A "mamamasan" for 25 years and the Balangay head of the Antigong Mamamasan. Aside from the role of safeguarding the wooden statue of the Señor during processions, the group is also in charged of the Catechism and orientation of the neophyte devotees on the "koda" (method and jargons) of a "mamamasan" during Traslación. Imon is a licensed architect based in Jubail, Saudi Arabia for 10 years, and comes home to attend the annual procession and Holy Week celebrations at the Basilica. On January 9, 2015, Imon is one who of those who brought his fellow Hijos and devotee, Renato Gurion ( 44 y/o), to a nearby hospital. Gurion eventually died of cardiac arrest during the first hours of Traslacion at the Quirino Grandstand. During the interview, Imon was asked whether he would continue his devotion after the incident; with great passion and vigor, he replies:

Sa akin, personal ... talagang mas lalong magtutuloytuloy 'yan ... Kung anuman ang mangyare ay kailangan nating tanggapin. 'Yung nangyare ke kapatid na Renato, kasama yan sa panata niya. Kasama 'yan sa panata ng bawat mamamasan. Hindi iyan dahilan upang itigil ang panata mo ... kasama iyon sa kaganapan ng iyong pamamanata."

${ }^{18}$ An interview with "Apolinario 'Tatay Boy' Maranan" at the Basilica Cafeteria (1:23 PM, 9 January 2014).

(C) 2016 Rhochie Avelino E. Matienzo http://www.kritike.org/journal/issue 19/matienzo december2016.pdf ISSN 1908-7330

(c) $)$ BY-NC-ND 
(To me it's personal ... the more that it will push through ... whatever happens, we must accept. What happened to Brother Renato is part of his sacred vow. It's all part of the devotees' sacred vow. It is not enough reason to stop ... it is all part of fulfilling one's sacred vow. $)^{19}$

The religious experiences of the above mentioned devotees indicate the following key elements: inwardness, subjectivity, and passion. Furthermore, the devotion may be seen in a two-fold intention ${ }^{20}$ of "panata": first, "hiling" (request), a personal appeal of both possible and impossible wish (cure of a terminal ailment, financial assistance, job request or promotion, or simply, the finding of a lost partner, etc.). Second, as an expression of "walang hanggang pasasalamat" (endless gratitude) which arises from a granted "hiling" (wish). The devotee pledges a lifetime exercise of "panata" (sacred vow) as a manifestation of "pagtanaw ng utang na loob" (debt within) where one continues to pay despite full awareness that he/she shall never be able to be compensated.

\section{Subjectivity, Passion, Inwardness, and the Leap of Faith}

The phrase "leap of faith" originates from an important passage in Concluding Unscientific Postscript where Kierkegaard remarks:

Faith is the objective uncertainty with the repulsion of the absurd, held fast in the passion of inwardness, which precisely is the relation of inwardness raised to the highest power. ${ }^{21}$

The definition involves elements essential to achieving genuine faith: first, the "objective uncertainty," or the indeterminate nature of one's object of faith. In the case of a devotee, one aims to be saved while exposing oneself to risk. Here, one finds no rational calculation to conceive the possibilities one may receive out of faith. Second, the "passion of inwardness" signifies the subjective nature of experiencing faith. Since an act of faith involves no rational

${ }^{19}$ An interview with "Raymond Gappi" through Sykpe Video Call (10:59 PM to 12:34 AM, 6-7 March 2015). In a local news interview, one devotee by the name of Josefino Quintero has stated that "I will keep doing this while I still have the strength, like my father did when he was still alive." See DJ Yap, Marlon Ramos, and Jaymee T. Gamil, "Millions Escort Black Nazarene," in Philippine Daily Inquirer (10 January 2011), PA1.

${ }^{20}$ See Milagros A. Aguinaldo, A Study on Filipino Culture: The Devotion to the Black Nazarene of Quiapo (Quezon City: MMA Publications, 2002), 26-31.

${ }^{21}$ Søren Kierkegaard, Concluding Unscientific Postscript to the Philosophical Crumbs, ed. and trans. by Alastair Hannay (Cambridge: University Press, 2009), 514. Italics added.

(c) 2016 Rhochie Avelino E. Matienzo

http://www.kritike.org/journal/issue 19/matienzo december2016.pdf

ISSN 1908-7330

(cc) BY-NC-ND 


\section{THE QUIAPO LEAP}

consideration (but not necessarily antithetical to it), the individual engages with a personal appropriation which he alone is capable of understanding. The phrase also pertains to the source of the utmost dynamism moving a believer to perform an act faith beyond human capacity and comprehension. In the Quiapo phenomenon, the sublime and deeply personal spirituality of the devotees appears absurd to observers. In a homily by Cardinal Luis Antonio Tagle during the 2012 Traslacion Eucharistic celebration, he describes these elements when he says, "to understand it, you need to be a devotee (because) outsiders do not understand." 22

\section{The Double-Movement of Faith and the Knight of Faith}

One of the central themes of Fear and Trembling is the notion of the "double-movement of faith." ${ }^{23}$ The movement involves two phases: the infinite resignation or the individual's act of renouncing everything for the sake of a higher telos through an ordeal (suffering); and, a repulsion of the absurd where something is revealed to the one possessing faith. The first is explained by the tragic heroes Jephthah, Brutus, and Agamemnon who represent the "knights of infinite resignation." 24 All of them sacrificed their children for a reason (love for country, justice, and honor). In the second predicament, Kierkegaard enthroned Abraham as the "knight of faith" who sacrificed his only son, Isaac, for no reason understandable to the human logic but either as an act of murder or plain insanity. On one hand, the knights of resignation remain within the bounds of the ethical (Hegel's Sittlichkeit, worldly understanding), while on the other hand, the knight of faith goes beyond and leaps into absurd faith. Here, the believer receives "something" provided by God.

\section{The Double Movement of Faith and the Possibility of "Miracles"}

A closer look at the double movement of faith provides a possible elucidation of what is revealed to the one who has faith. I wish to invoke here

\footnotetext{
${ }^{22}$ Luis Antonio Cardinal Tagle (Archbishop of Manila), as quoted in Jeannette I. Andrade, Jocelyn R. Uy, and Philip Tubeza, “Millions Defy Terror Alert," in Inquirer.net (10 January 2012), <http://newsinfo.inquirer.net/125277/millions-defy-terror-alert $>$, 28 November 2013.

${ }^{23}$ Kierkegaard, Fear and Trembling, 35-37, 43, 48.

${ }^{24}$ Agamemnon sacrificed daughter Iphigenia to secure travel for the Greeks and sail to Troy; the Biblical character Jephthah vowed to kill the first one he meets on his way back to his city after a battle for the sake of Israel, that one happens to be his daughter and last, the Roman consul Brutus who executed his two sons for conspiracy to kill the king. All the three sacrifices involve their own kin and each are acceptable to the telos accepted by the society as values. See ibid., 57-61.
}

(C) 2016 Rhochie Avelino E. Matienzo

http://www.kritike.org/journal/issue 19/matienzo december2016.pdf

ISSN 1908-7330

(cc) BY-NC-ND 
the phrase "repulsion of the absurd" found in Kierkegaard's definition "faith," where the existential meaning is revealed to the individual. ${ }^{25}$ During one's religious experience, one trusts the object of faith despite uncertainty via total surrender (e.g., offering of material wealth, time, honor, knowledge, morality, child, even one's own life). In return, existential meaning is revealed. This existential meaning, however, may appear absurd to observers.

Another contention is that the same existential meaning refers to the experience of a "miracle." In Kierkegaardian parlance, the meaning defies rationality in lieu of a higher truth. Faith is, thus, a violation of man's rational nature. Paradoxically, it provides the individual the highest meaning in life. In the case of Abraham, he absurdly followed and miraculously received back Isaac, fathered all nations, inherited the Promised Land, continued his legacy, restored his honor, and became a blessing to many nations as the multitude of stars in the heaven; all by trusting the wisdom from the "divine insanity." This process of making an impossible possible becomes possible only by means of the individual's "leap of faith." This is realized in one's subjectivity, passion, and inward experience of meeting the paradoxicality of Christ. ${ }^{26}$ Kierkegaard further points out that a "miracle" of this sort may also happen in the present age: "for our generation does not stop with faith, does not stop with the miracle of faith, turning water into wine-it goes further and turns wine into water." 27

\section{The Panata of "Hiling" and "Pasasalamat" as the Double Movement of Faith}

For the fifteen-year devotee, Erlinda Dizon, the 2015 Traslación became the most significant moment in her life. Her yearly sacred vow is intended for her 39-year-old son named Alexander who suffers difficulty in speaking and chronic memory loss. On July 11, 2014, Alexander got lost while having a meal at a fast food restaurant in a nearby city. After six months of failed searching, Erlinda joined the annual Traslación, but this time, with a very personal intention, i.e., to find her only son. As the slow paced procession headed towards the corner of Burgos Street and Roxas Boulevard in Manila, she witnessed a man being trodden and trampled upon near the jostling crowd. Out of pity, she pulled the man to safety, just in time, away

${ }^{25}$ Kierkegaard, Concluding Unscientific Postscript, 514.

${ }^{26}$ The paradoxicality of Christ pertains to "God in existence"; by His being divine yet human, finite and infinite, and eternal but temporal at the same time. See ibid., 133, 279. This truth is beyond logical demonstration but a paradox of existence which transcends rationality. For Kierkegaard, it is through "contradiction, that is the absurd which alone one can have faith." Ibid., 184.

${ }^{27}$ Ibid., 37. Emphasis, added. 


\section{THE QUIAPO LEAP}

from the approaching sea of devotees. Erlinda was surprised to notice the scar in right leg of the man, and despite the change in his physical appearance, Erlinda was sure it was her son, Alexander. Erlinda found her lost son amidst the sea of devotees on the feast of the Black Nazarene, which happened to be her $67^{\text {th }}$ birthday. This account belongs to only one of the multitude claims of "himala" (miracle) among the devotees.

Through "faith by virtue of the absurd," Erlinda surrendered her weakened and aged body to a "collective frenzy of masculine strength" 28 in virtue of her a decision based not on "human calculation" but on a "leap of faith." Enclosed with her faith is the special kind of wisdom only she and the Nazarene Christ understand. For Kierkegaard, this is the "new category of understanding" existential truths that are absurd to many but meaningful to the believer. ${ }^{29}$ In Erlinda's worldview, her physically and mentally challenged son is her "everything," thus, the loss of Alexander is the loss of her life's meaning. Kierkegaard explains this: "the one who lost the beloved has in a sense lost sons and daughters... and along with it the vitality and meaning of life." 30

I am suggesting that "himala" or "miracle" is the existential meaning behind the absurdity of faith. The wisdom unveiled when one leaps into the abyss of uncertainty. Since, for Kierkegaard, an individual "live(s) happily not to find rest in the pain of resignation but to find joy by virtue of the absurd." 31 The joyful sacrifice one does not understand but only live. It is here, the double-movement of faith in the context of devotion illustrates the "panata" metamorphosis from "panata ng hiling" (sacred vow as a form of request) towards a "panata ng pasasalamat" (sacred vow as a form of gratitude). In the first, the devotee sees no fear of death before the perilous ritual in the ardent belief that his/her wish shall be granted by the Señor. It is at this instance non-devotees find Quiapo popular devotion idolatrous, irrational, fanatic and superstitious. The second phase is the act of receiving God's gift, manifested in one's "utang na loob" performed as a "panata" of "walang hanggang pasasalamat" (perpetual gratitude). The devotee's faith, therefore, is the existential situation where one resigns everything to the object of faith, and in return, God enacts a reward received by the believer by way of "himala."

\footnotetext{
${ }^{28}$ Jose Alain Austria, "Hijos de Enero Nueve: The Black Nazarene Procession as a Male Rite of Passage" in Manila: Selected Papers of the 20th Annual Manila Studies Conference, July 28-29, 2011 (Manila: Manila Studies Association and the National Commission for Culture and the Arts, 2012).

${ }^{29}$ Kierkegaard, Fear and Trembling, 60.

${ }^{30}$ Ibid., 198. Emphasis added.

${ }^{31}$ Ibid., 50.
}

(C) 2016 Rhochie Avelino E. Matienzo

http://www.kritike.org/journal/issue 19/matienzo december2016.pdf

ISSN 1908-7330

(c) BY-NC-ND 
What the devotees consider "himala" may not merit the recognition of mainstream religion and may appear entirely unusual to the logic of modern sciences, because the transformation is subjectively happening within the personal level. This "personal miracle," hence, makes the true devotee a knight of faith who obtains the greatest blessings in life via an absurd act of worship. "Himala" is the existential meaning understood through faith by virtue of the absurd that uniquely explains the humanly impossible-made-possible during the Quiapo devotion. In a way, the first Traslación of 1787 will never reach its present magnitude and religious import without genuine narratives of received blessings in an extremely extraordinary way such as those of "himala." These blessings comprise a "himala" that provides one his/her life's meaning; a meaning that enables self-transcendence which transforms one's manner of believing, thinking, and living in general.

\section{Conclusion, Limits, and Implications}

I wish to conclude that the religious experience during the Black Nazarene popular devotion may be understood in the context of Kierkegaardian existentialist faith for the following reasons:

First, the devotion contains elements essential to the Kierkegaardian faith: inwardness, subjectivity, and passion. The faith during devotion is subjectively appropriated in the performance of "panata" as one submits total self to the object of faith. The act is not understandable to many yet meaningful to the individual subject. The zealousness during "panata" proceeds from the devotee's inwardness motivated by personal intentions communicated to God through the devotion. The ritual is passionately performed, appearing strange and oftentimes criticized as religious "fanaticism," "irrationality," "idolatry," and "paganism" by observers.

Second, the two-fold intention of "panata": as "hiling" (wish) and "pasasalamat" (gratitude), signifies the concrete experience of the Kierkegaardian "double movement of faith." During Traslación, the devotee "infinitely resigns" everything, thereby, experiences suffering and, in return, receives God's reward. What God provides the devoted-believer is the existential meaning wrapped in "absurdity" appropriated solely by faith.

Third, this existential meaning is what the devoted-believer claims as "himala" (miracle). Such is evident in the transition from a "panata of hiling" (vow as a wish) to the "panata" of "walang hanggang pasasalamat" (vow as perpetual gratitude). This devotion is a lifetime "panata" in the context of "utang na loob"; a perpetual debt one promises to recompense out of the extraordinary blessing or "himala" obtained in one's performance of faith.

(c) 2016 Rhochie Avelino E. Matienzo

http://www.kritike.org/journal/issue 19/matienzo december2016.pdf

ISSN 1908-7330

(cc) BY-NC-ND 


\section{THE QUIAPO LEAP}

From these, the Quiapo popular devotion, therefore, may now be viewed through a philosophical lens in the light of Søren Kierkegaard's philosophy, particularly, the existentialist notion of faith. Existential faith may not account for the validity and authenticity of all the religious experiences, as well as the "miracles" claimed, by the millions of devotees present in the annual Traslación. However, a careful reading of the Kierkegaardian "leap" and a keen observation of these rituals may shed light on the present understanding of popular devotions. To some extent, this contributes to the prevailing theories presented by the social scientists and religious experts on the phenomenon, and thus, this study suggests a multidisciplinary approach to uncovering the hidden layers of meaning of such unique Filipino religiosity.

This study also suggests that popular devotions, despite oddity in practices, may serve as meaning-seeking-opportunity and personal inspiration to pursue life among the common folks amidst the onslaught of the modern day living. Since, the majority of the devotees belong to the "masa," whose ways are not always amiable to the lens of the educated few, the study of Quiapo popular devotion shall serve as a significant voice of those people belonging to the social margin.

Finally, the findings of this study are a noteworthy invitation among theologians and religious experts to further explore this kind of spirituality in order to develop more actual and effective means that will serve rightfully the Christian missionary aims of today's Filipino faith.

Department of Philosophy, University of Santo Tomas, Philippines

\section{References}

Aguinaldo, Milagros A., A Study on Filipino Culture: The Devotion to the Black Nazarene of Quiapo (Quezon City: MMA Publications, 2002).

Andrade, Jeannette I., Jocelyn R. Uy, and Philip Tubeza, "Millions Defy Terror Alert," in Inquirer.net (10 January 2012), $<$ http://newsinfo.inquirer.net/125277/millions-defy-terror-alert $>, \quad 28$ November 2013.

Austria, Jose Alain, "Hijos de Enero Nueve: The Black Nazarene Procession as a Male Rite of Passage" in Manila: Selected Papers of the 20th Annual Manila Studies Conference, July 28-29, 2011 (Manila: Manila Studies Association and the National Commission for Culture and the Arts, 2012).

Bantungan, Brian, "Recognizing Frames and Constructing Realities: The Implications of the Integration of Actual, Virtual and Augmenting Realities of the Optical Mediascape of Quiapo," paper presented at

(C) 2016 Rhochie Avelino E. Matienzo

http://www.kritike.org/journal/issue 19/matienzo december2016.pdf

ISSN 1908-7330

(cc) BY-NC-ND 
Media in Transition 6: Stone and Papyrus, Storage and Transmission, Massachusetts Institute of Technology, 24-26 April 2009.

Brown, Sarah and Firefly360, "The Annual Feast of the Black Nazarene," CNN iReport (9 January 2013), <http://ireport.cnn.com/docs/DOC-907647>, 15 May 2013.

Chan, Peter C., "Popular Religion, the Liturgy, and the Cult of the Dead," in East Asian Pastoral Review, 42:1-2 (2005), in East Asian Pastoral Institute (2005), <http://www.eapi.org.ph/resources/eapr/east-asian-pastoralreview-2005/volume-42-2005-number-1-2/popular-religion-theliturgy-and-the-cult-of-the-dead/>, 18 July 2013.

Domingo, Eduardo, "Opium or Catalyst?: The Ambivalence of Religious Symbols in Social Change," in And God Said: 'Hala!' Studies in Popular Religiosity in the Philippines, ed. by Jaime A. Belita (Manila: De La Salle University Press, 1991).

Gaerlan, Ma. Carmen R., "Hidden from the Clever: An Initial Study on Selected Religious Beliefs and Practices of Filipino Popular Catholicism," in And God Said: 'Hala!' Studies in Popular Religiosity in the Philippines, ed. by Jaime A. Belita (Manila: De La Salle University Press, 1991).

Genova, Windsor, “Thousands of 'Black Jesus' Devotees Join Manila Procession Amid Bomb Threat" International Business Times (9 January 2012), <http://www.ibtimes.com.au/thousands-black-jesusdevotees-join-manila-procession-amid-bomb-threat-1292219>, $\quad 14$ January 2014.

Guidaben, Agatha, "March of the multitudes: Nazarene procession grows every year," in GMA News Online (9 January 2014), $<$ http://www.gmanetwork.com/news/story/343106/news/nation/mar ch-of-the-multitudes-nazarene-procession-grows-every-year $>, \quad 15$ January 2014.

Hegina, Aries Joseph and Bong Lozada, " 2 dead, 2 hurt by electric shock in 19-hour Black Nazarene 'traslacion,'"' in Inquirer.net (10 January 2015), <http://newsinfo.inquirer.net/663671/1-dead-2-electrocutedin-19-hour-black-nazarene-traslacion $>, 10$ January 2015.

Ignacio, Jose Clemente F., "Understanding the Devotion to the Black Nazarene," paper presented at the National Liturgical Congress, Loyola School of Theology, Quezon City, 19 January 2011.

Kierkegaard, Søren, Concluding Unscientific Postscript to the Philosophical Crumbs, ed. and trans. by Alastair Hannay (Cambridge: University Press, 2009). Fear and Trembling/Repetition, ed. and trans. by Howard Hong and Edna Hong (New Jersey: Princeton University Press, 1983). 


\section{THE QUIAPO LEAP}

Matienzo, Rhochie Avelino E., An interview with "Apolinario 'Tatay Boy' Maranan" at the Basilica Cafeteria (1:23 PM, 9 January 2014). An interview with "Glaiza" at Park and Ride, Lawton, Manila (9 January 2014, 6:32 PM). An interview with "Raymond Gappi" through Sykpe Video Call (10:59 PM to 12:34 AM, 6-7 March 2015). "Kierkegaard in Quiapo! An Existential Look at the Black Nazarene Popular Religious Experience," in Scientia (June 2014).

Mercado, Leonardo N., ed. "Lakaran: A Filipino Way of Proclaiming Christ," in Studia Missionalia, 51 (2002).

Obusan, Teresita B., Mystic or Mistake: Exploring Filipino Mysticism (Quezon City: Institute of Spirituality in Asia, 2008).

Orleans, Myron, "Phenomenology," in Encyclopedia of Sociology, $2^{\text {nd }}$ ed., vol. 3, ed. Edgar F. Borgatta and Rhonda J.V. Montgomery (New York: Macmillan Reference USA, 2000).

Pagulong, Charmie Joy, "Timeline: Deaths, injuries, during Quiapo procession," in The Philippine Star Global (8 January 2012), $<$ http://www.philstar.com/headlines/765471/timeline-deathsinjuries-during-quiapo-procession $>, 18$ January 2014.

Paul VI, "Sacrosanctum Concilium," in The Holy See (4 December 1963), $<$ http://www.vatican.va/archive/hist councils/ii vatican council/do cuments/vat-ii const 19631204 sacrosanctum-concilium en.html>.

Philippine News Agency, "2014 'Traslacion' of the Black Nazarene takes almost 19 hours," in Interaksyon (10 January 2014), <http://interaksyon.com/article/78428/2014-traslacion-of-the-blacknazarene-takes-almost-19-hours>, 11 January 2014.

Raas, Bernhard, Popular Devotions: Making Popular Religious Practices More Potent Vehicles of Spiritual Growth (Manila: Divine World Publications, 1992).

Talisayon, Serafin, "Patotoo, An Indigenous Concept of Validity and Some Implications," in Hiyang: Papers of the Colloquium on Research Methodologies in the Study of Spirituality in the Philippines (June 28-30, 2004) (Quezon City: Carmelite Center for Spirituality, 2005).

Tubeza, Philip, "Quiapo Priest: Filipino Devotion to Black Nazarene Not Idolatry," in Inquirer.net (9 January 2013), $<$ http://newsinfo.inquirer.net/337495/quiapo-priest-filipinodevotion-to-black-nazarene-not-idolatry>, 9 January 2013.

Uy, Jocelyn R., “Black Nazarene Devotees Displayed 'Excess Fanaticism,' Says Quiapo Priest," Inquirer.net (11 January 2012), $<$ http://newsinfo.inquirer.net/125993/black-nazarene-devoteesdisplayed- $\%$ E2\%80\%98excess-fanaticism $\% \mathrm{E} 2 \% 80 \% 99$-says-quiapopriest $>, 15$ May 2013. 
Yap, DJ, Marlon Ramos, and Jaymee T. Gamil, “Millions Escort Black Nazarene," in Philippine Daily Inquirer (10 January 2011), PA1. 